\title{
QSAR of heterocyclic antifungal agents by flip
}

\section{regression}

\author{
Omar Deeb ${ }^{1}$, Brian W. Clare ${ }^{2, *}$ \\ ${ }^{1}$ Faculty of Pharmacy, Al-Quds University, P.O. Box 20002 Jerusalem, Palestine. \\ ${ }^{2}$ School of Biomedical and Chemical Sciences, The University of Western \\ Australia
}

35 Stirling Highway, Crawley, WA 6009, Australia

Tel. +61 8 64884462, Fax +61 8 64881005, email bwc@theochem.uwa.edu.au

\begin{abstract}
QSAR analysis of a set of 96 heterocyclics with antifungal activity was performed. The results reveals that a pyridine ring is more favorable than benzene as the 6membered ring, for high activity, but thiazole is unfavorable as the 5-membered ring relative to imidazole or oxazole. Methylene is the spacer leading to the highest activity. The descriptors used are indicator variables, which account for identity of substituent, lipophilicity and volume of substituent, and total polarizability. Unlike previously reported results for this data set, our fits do not exceed the limitations set by the nature of the data itself.
\end{abstract}

Keywords: QSAR, Flip regression, antifungals, AM1. 


\section{Introduction:}

Recent decades have witnessed increasing efforts for developing new antifungal drugs that are capable to inhibiting various diseases related to Candida albicans species, [1] Most fungi are completely resistant to the action of antimicrobial drugs. Only a few substances have been discovered which exert an inhibitory effect on the fungi pathogenic for man, and most of these are relatively toxic [2]

Consequently, spurred by the need of new antifungal agents and the fact that many effective antimicrobial drugs possess heterocyclic systems in their structure, some novel derivatives were synthesized during the past decade [3].

Apparently, the design of new pharmacological drugs possessing novel modes of action is required to reduce the dramatic increase in frequency of systemic infections along with the newly appearing fungal species, the development of resistance to the present azole therapies and also for diminishing the high toxicity of polyenes [4-6] A wide number of known effective antimicrobial remedies include heterocyclic systems in their structure, like imidazoles, quinazolines, benzazoles and oxazolo (4-6) pyridines [3,6-11] although none of these substances exhibit simultaneously an optimally desired spectrum, potency, pharmacological properties, etc.

Nowadays, the QSAR theory is extensively applied for studying the effects and antifungal potencies of compounds [11-14] A recent QSAR study of the 96 antifungal compounds was recently reported [15] using a number of topological descriptors. Very good $\mathrm{R}^{2}$ values, as high as 0.9370 were reported. 
Such good correlations seem implausible, given that the data was of narrow range and was obtained by a twofold serial dilution technique. [7-11, 16] Starting from a fixed concentration (in mg/l) the solutions were successively tested and diluted twofold and retested until inhibition was obtained, which was noted as the inhibitory concentration. The concentration was then divided by the molecular weight, giving the MIC which is the result with which we work.

Thus the inhibitory concentration is known at best to within a factor of two, which precludes accuracy in the log inhibitory concentration data of better than $1 / 2 \log 2$, or 0.15 in the range of least active to most active drug, which was 1.041 in logarithmic terms. We have simulated data using the reported logarithmic concentration plus a uniformly distributed random error in the range \pm 0.15 and carried out a linear regression of the data plus the simulated error on the data, and in 5 trials obtained a mean $\mathrm{R}^{2}$ of 0.8866 and a mean $\mathrm{S}$ of 0.084 , with standard deviations 0.003 and 0.002 respectively. This represents the best that can be expected in any QSAR study on this data set, assuming no other source of error.

The results of Duchowicz et al. [15] are thus over-fitted, regardless of the statistical techniques that were used. The present contribution is a reanalysis of this data set using our flip regression technique [17], to allow for isostericity of the various fused bicyclic ring systems found in the 96 compounds studied. We used variables appropriate for a combined classical Hansch Free-Wilson approach. Indicator variables were used for the various heterocyclic rings and for the linkers connecting the phenyl ring to the heterocyclic system, and the lipophilicities and volumes of the substituents on the aromatic rings, served as Hansch-type variables. 
In continuation to our previous studies, e.g. [17-20], all in vitro inhibitory activities against Candida albicans species are expressed as pMIC $[\mathrm{M}]=-\log (\mathrm{MIC}[\mathrm{M}])$, with the quantity $\mathrm{MIC}(\mathrm{M})$ representing the minimum inhibitory concentration in molar units, is modelled in this study with the descriptors mentioned above using Flip regression technique. All in vitro inhibitory activities of 96 heterocyclics expressed as pMIC are shown in Table 1.

A problem arises from the symmetry of the parent molecule; to deal with this problem, we use the program FLIPSTEP, a component of the MARTHA ${ }^{\mathrm{a}}$ statistical package, which has been described previously $[17,18]$.The flip regression program is applicable to the potentially $\mathrm{C}_{2 \mathrm{v}}$-symmetric fused-ring heterocyclic. The phenyl ring, also of $\mathrm{C}_{2 \mathrm{v}}$ symmetry, bears only a 4-substituent, so we do not apply the flip procedure to it, as the full symmetry of this ring is not broken.

The fused ring system on the other hand has its symmetry potentially broken by the pyridine nitrogen $\mathrm{X}$ and the $\mathrm{N}$ or $\mathrm{O}$ atom $\mathrm{Y}$. We need to consider whether or not the location of these atoms is relevant to activity, or whether only the position of the R1 and R2 groups is relevant. Indeed it remains to be shown that even the positions of these are significant determinants of activity.

\section{Materials and Methods}

The molecules were set up with HyperChem [21] and optimised first with one picosecond of molecular dynamics at the molecular dynamics, and finally at the AM1 level with Mopac 6 [22] An AM1 optimization was considered adequate for these

compounds, as AM1 was developed and parameterized for common organic 
structures such as these. Then AM1 energy calculations were carried out on the optimized geometries using MOPAC 93 [23] software.

The lipophilicities and volumes of the substituents on the aromatic rings, calculated by Hyperchem [21] were used as Hansch-type variables. The variables used in this study are listed in Table 2. The descriptors in Table 2 were correlated with the activities taken from the literature [15] for the compounds listed in Table 1 with the programs flipstep [17], fliprand and flippred [24], which have been described previously.

Flip regression is a technique for obtaining QSARs in molecules that have symmetry. It was first employed by Kishida and Manabe in 1980 [25], to study the effect of lipophilicity of substituents in some derivatives of benzenedisulfonamide. In the context of the present problem, the molecules are heterocyclic isosteres and which have a possible symmetry plane bisecting the 5- and 6-membered fused rings, as shown as dashed line in Figure 1. The atom $\mathrm{X}$ for example may be $\mathrm{CH}$ or $\mathrm{N}$. This may influence activity through an electronic effect that increases or reduces the activity of the drug, and through symmetry. if $\mathrm{X}$ is $\mathrm{CH}$ and $\mathrm{Y} \mathrm{NH}$ the molecule is symmetrical (allowing for tautomerism) and it will be immaterial whether a particular substituent is in the $\mathrm{R} 1$ or $\mathrm{R} 2$ position. If $\mathrm{X}$ is $\mathrm{N}$ and $\mathrm{Y}$ is $\mathrm{NH}$ the two positions are isosteric, and one of the two possible orientations may or may not be favoured over the other. The performance of flip regression on simulated data has been described previously. [17] Even if the molecule is not formally symmetric the asymmetry may not be reflected in the activity data. In the absence of experimental structure information only a calculation can indicate whether this is so. 
For a particular case, the R1 and R2 groups may be exchanged, corresponding to "flipping" the molecule through the symmetry plane. Where there are $\mathrm{N}$ different molecules, and there are 2 possibilities for each molecule, there are $2^{\mathrm{N}}$ possible alternative arrangements. Each of these arrangements can be analyzed in a regression equation. Physically, the molecule will enter that arrangement on the receptor that minimizes its binding energy. There are $2^{\mathrm{N}}$ different regression equations that must be solved. That regression that maximizes the Fisher variance ratio, or equivalently that maximizes $\mathrm{R}^{2}$, is chosen.

Of course, if $\mathrm{N}$ is at all large, this results in an extremely large number of regressions. To render this task manageable we adopt the combinatorial optimization technique of simulated annealing. The progress of the calculation is tracked by maintaining two $\mathrm{N}$ element arrays. The first of these, the flip status starts with a value of 1 for each element when all the substituents are arranged as they are initially set up in Table 1, and the value is changed to -1 when that molecule is flipped.

At the conclusion of the calculation, when the flip statuses reflect the orientation of each molecule in the best-fit position, each molecule in turn is flipped with no change to the others, and the decrease in goodness of fit is determined. A Student's $t$ test determines whether or not the change in this one compound significantly reduces the quality of the fit, for each compound in turn. If it is not significant, this means that the relevant compound can lay either way on the receptor. If it is significant the current orientation is preferred. The probability value associated with the compound is stored in the second array, the flip significance. 
There are two consequences of this procedure that must be borne in mind. The first is that an inflation of significance occurs. Random numbers subjected to this procedure can give apparently highly significant regressions. The procedure cannot however improve on an already optimal arrangement. The only way currently known to validate the procedure is repeated randomization of the dependent variable. The correlation coefficient for the optimal arrangement is determined. Then the dependent variable is repeatedly randomly reassigned to the independent variable matrix, and the correlation coefficient recalculated.

The distribution of correlation coefficients is very non-normal, but a simple transformation, Fishers $v$ (or $z$ ) transformation, can normalize it. The calculated correlation coefficient from the flip regression is fixed, and has zero variance. If $\mathrm{R}$ is the correlation coefficient from the randomisation trial, the quantity $v=\frac{1}{2} \ln \frac{1+R}{1-R}$ is normally distributed, and if we have a number of $\mathrm{R}$ values from the randomisation trials we can take the mean and variance of their $v$ values and test the hypothesis that the obtained $v$ is greater than the mean of those generated from the randomised data.

The calculated significance level improves with the number of trials, which is an undesirable feature. We typically carry out 5000 randomizations, and in this number of trials we never encounter in a successful flip regression a situation where one of the randomised $v$ values is greater than that obtained in the actual regression. The test of $v$ against the mean of the randomised values to some degree quantifies this. While in classical regression a probability value of 0.05 or less is usually regarded as 
significant, we would tend to discount any value from the randomisation trial much greater than approximately $10^{-5}$.

Because in this procedure the matrix of predictor variables is preserved, the influence of colinearity is identical in both original regression and the randomisation trials. The second point is that there are always two equivalent solutions to a problem, with flip statuses differing by a factor of -1 . Which of the two solutions is obtained in any particular run is a matter of chance. The flip status thus has relative significance only.

The program flipstep is a backwards-stepwise variable selection procedure. It starts with all of the initial variables in the regression, and eliminates single variables, or flippable pairs of variables, one at a time, on the basis of colinearity with other variables in the equation, determined by the variance inflation factor, or of the statistical significance of the variable based on a $t$ test. The maximum tolerated colinearity and significance level may be set by the user. Flippable pairs of variables must be treated as a whole, and either both are included, or both deleted.

Because a single run of simulated annealing frequently gives a non-optimal solution, Flipstep does by default at least 5 and at most 15 independent runs and selects the best in terms of Fisher $\mathrm{F}$ ratio. The selection is based on an exact equality test, rather than equality within a tolerance, and is carried out in double precision on a 32-bit platform. The resolution is thus approximately 1 in $10^{17}$. The fact that the equality test is usually met many times in a given run, particularly when variable selection is nearly complete, suggests that Flipstep is consistently finding the same, relatively small subset of solutions out of the vast number possible. 


\section{Results and Discussion}

The different descriptors used in this study are explained in Table 2. The Supplementary material Table S1 summarizes the variables listed in Table 2 for the 96 compounds in Table 1.

Table 3 show the results of FLIPSTEP calculation carried out on the variables shown in Table 2 without flipping any variables. FLIPSTEP calculations resulted in removing $\mathrm{I}\left(\mathrm{CH}_{2} \mathrm{O}\right), \mathrm{I}\left(\mathrm{CH}_{2} \mathrm{NH}\right), \mathrm{LDIG}, \mathrm{R} \pi, \mathrm{R} 1 \mathrm{~V}, \mathrm{R} 2 \pi, \mathrm{RV}, \mathrm{I}(\mathrm{Imi}), \mathrm{I}\left(\mathrm{C}_{2} \mathrm{H}_{4}\right), \mathrm{R} 2 \mathrm{~V}$ because they are statistically insignificant. $\Delta \mathrm{H}_{\mathrm{S}}$ and $\Pi$ were deleted due to colinearity. Flip regression gives the equation:

$$
\begin{aligned}
& \mathrm{pMIC}[\mathrm{M}]=-0.0698(8.3) \mathrm{R} 1 \pi+0.2303(5.1) \mathrm{I}(\mathrm{Pyr})-0.2542(3.4) \mathrm{I}(\mathrm{Thi})+0.3411(9.0) \\
& \mathrm{I}\left(\mathrm{CH}_{2}\right)+0.1580(4.1) \mathrm{I}\left(\mathrm{CH}_{2} \mathrm{~S}\right)+4.015 \\
& \mathrm{~N}=96, \mathrm{R}^{2}=0.693, \mathrm{~S}=0.127, \mathrm{~F}=40.60, \mathrm{Q}^{2}=0.659
\end{aligned}
$$

Here $\mathrm{N}$ is the number of compounds in the regression, $\mathrm{R}^{2}$ is the square of the multiple correlation coefficient, $\mathrm{S}$ is the root mean square error, $\mathrm{F}$ is the Fisher variance ratio and $\mathrm{Q}^{2}$ is the $\mathrm{R}^{2}$ based on the leave-one-out technique. It should be noted that the $\mathrm{Q}^{2}$ value is $\mathrm{Q}^{2}$ from classical regression, and so does not have its usual significance. It assumes that all flip statuses are correct, and known in advance, an assumption that is not warranted. The numbers in parentheses are Student's $t$ values, with values greater than approximately 2 indicating significance at the 0.05 probability level. The smallest of them, that for I(Thi) corresponds to a probability value of 0.00105 . Thus 
all variables left in the equation are very highly significant. $R^{2}$ is 0.693 and $S 0.127$, which means that there is still some unexplained variance in the data, given that the minimum values imposed by twofold dilution technique on the error in activity are 0.887 and 0.084 respectively.

Performing flip regression analysis while R1V is flipped with R2V and R1 $\pi$ is flipped with $\mathrm{R} 2 \pi$ gives the equation:

$$
\begin{aligned}
& \mathrm{p} M I C[\mathrm{M}]=0.00078(2.7) \Pi-0.00047(1.3) \mathrm{R} 1 \mathrm{~V}-0.07136(12.5) \mathrm{R} 1 \pi+0.00271(4.9) \\
& \mathrm{R} 2 \mathrm{~V}+0.10119(7.9) \mathrm{R} 2 \pi+0.27233(8.2) \mathrm{I}(\mathrm{Pyr})+0.05504(2.4) \mathrm{I}(\mathrm{Imi})-0.22709(4.3) \\
& \mathrm{I}(\mathrm{Thi})+0.37586(14.0) \mathrm{I}\left(\mathrm{CH}_{2}\right)+0.07112(2.7) \mathrm{I}\left(\mathrm{CH}_{2} \mathrm{~S}\right)+3.637 \\
& \mathrm{~N}=96, \mathrm{R}^{2}=0.8772, \mathrm{~S}=0.082, \mathrm{Q}^{2}=0.8368, \mathrm{~F}=60.73, \mathrm{P}=1.6 \times 10^{-38}
\end{aligned}
$$

Flipstep calculations resulted in deletion of $\mathrm{I}\left(\mathrm{CH}_{2} \mathrm{O}\right), \mathrm{I}\left(\mathrm{C}_{2} \mathrm{H}_{4}\right), \mathrm{I}\left(\mathrm{CH}_{2} \mathrm{NH}\right)$, $\mathrm{R} \pi$, and $\mathrm{RV}$ because of low significance and $\Delta \mathrm{H}_{\mathrm{S}}$ because of colinearity with other descriptors.

Table 4 show FLIPSTEP results for the model suggested in equation (2). Here R1V is obviously of very poor significance, but it must be included in the model because its companion term $\mathrm{R} 2 \mathrm{~V}$ is of very high significance, and neither is meaningful in the absence of the other. $\mathrm{P}$ is the probability value calculated by fliprand for 5000 randomizations. This value cannot be inflated by the flip procedure. This test is similar to that recommended by Topliss et al., and because the correlation structure of the independent variables is preserved is free from the criticism that random independent variables are unrealistic because they are uncorrelated. 
From the Student's $t$ values the most significant term is $\mathrm{I}\left(\mathrm{CH}_{2}\right)$, followed by $\mathrm{R} 1 \pi$. Note that $\mathrm{R}^{2}$ and $\mathrm{S}$ have now quite closely approached the limit set by the error in the activity data. Allowing volume and lipophilicity of group R1 to swap with that of group R2 almost completely explains the remaining variance in the data, and no further improvement is possible. This is not to say that the other variables in Table 2 are without effect, only that any such effects cannot be determined from this particular data set.

The results indicate that within the limits of the data set and with very high confidence the R1 and R2 positions are opposite in their preference for lipohilic substituents, that bulk of only one of the two is important, and that lipophilicity is more important than volume. A pyridine ring is preferable to benzene for the 6membered ring with a very high degree of confidence, and imidazole or oxazole to is preferable to thiazole for the 5-membered ring, with a lesser degree of confidence. A methylene group is by far the preferred spacer $\mathrm{Z}$. Of the indicator variables left in the final equation only I(Pyr) correlates significantly with the flip status. This is indicative that apart from the pyridine nitrogen there is no strong preference on the part of the heterocyclic structure for either orientation - that is, the three 5-membered heterocycles are truly isosteric.

Table 5 summarizes the observed activity as well as the estimated activity according to the multilinear regression carried out on the variables in equation (2) while Fig. 2 graphically demonstrates these results. 


\section{Performance of FLIPSTEP}

Five consecutive runs of flipstep using default settings gave apparently identical results on the full data set, including all flip significances, but there were differences in flip status that reflected the corresponding flip significance. As shown in Table 6 significances were exactly 1 where R1 and R2 were both $\mathrm{H}$, as would be expected, and were very close to 1 when $\mathrm{R} 1$ was $\mathrm{NH}_{2}$ and $\mathrm{R} 2$ was $\mathrm{H}$, indicating little preference of the two sites for $\mathrm{NH}_{2}$ over $\mathrm{H}$.

In all other cases significances were well below 0.05, indicating quite strong preferences for one orientation of the substituents on the isosteric ring system over the other. The failure of the indicator variables I(Thi) and I(Imi) to correlate with flip status is indicative that the three 5-membered rings are truly isosteric.

A validation experiment was carried out as follows: The full data set was split into a training set and test set using the Martha routine Split, setting at 0.77 the probability of the compound being considered going into the training set. Because of the stochastic nature of this procedure training sets were not all of equal size. This was done eight times. A full Flipstep run including completely independent variable selection was carried out on each training set, and the program Flippred was then run on the flip-optimized, variable-selected result and the corresponding test set. Flippred does a flip regression without variable selection on the already variable-selected training set and applies the calculated coefficients to the similarly variable-selected test set. 
This results in two predictions for each member of the test set, a high and a low prediction. Because we believe that the activity of a drug reflects its energy of binding to its receptor we assume that the high prediction is the valid one. We carried out a univariate regression of the observed activity of the antifungal on the high-predicted activity and we report the results in Table 7 . All runs except run 7 were statistically significant at the 0.05 level. When the results of the 8 trials are pooled the overall significance of the difference between the original and randomised regressions comes to $1.9 \times 10^{-9}$. In most cases the $\mathrm{R}^{2}$ value is poor, but this is to be expected given the low accuracy of the data, as discussed in the Introduction. Thus although the prediction results in this data set are not sufficiently accurate to be practically useful, the overall correlation is of very high statistical significance.

To confirm the adequacy of the settings in Flipstep for simulated annealing we carried out 10 Flipstep runs with each of 11 cooling regimes. The starting temperature was the same in all cases. The results are reported in Table 8 . The cooling rate and number of cycles in Flipstep are not adaptive, but are set in advance. By default we use a cooling rate of 0.2 and 10000 cycles. Unlike most simulated annealing protocols we are reducing the temperature by a factor of 1-C/100 every cycle, where $\mathrm{C}$ is the cooling rate, rather than in constant temperature stages as is usually done. The cooling is exponential in nature.

As may be seen from Table 8 the default regimes produces 10 out of 10 runs with $\mathrm{R}^{2}$ of 0.8772 , and can be varied quite widely without affecting this. It fails catastrophically when the rate is reduced to 0.05 , but recovers completely when the 
number of cycles is doubled. This is because under the first of these conditions the final temperature is not low enough to stabilize the annealing.

The results deteriorate only slowly as the cooling rate is increased, giving rise to extra, marginally poorer regression results. These results show that for this problem our default cooling procedure is conservative, and in fact for most problems we do not have to vary it.

When inspected, even results giving identical $\mathrm{F}$ and $\mathrm{R}^{2}$ results are not identical, but differ in some flip statuses. All of the flip significance results in a sample of 10 runs with the default cooling parameters were identical, but there were differences in the corresponding flip statuses, rarely when the flip significance values were very small, becoming more common when the significance became larger, deteriorating to become completely random when the significance (i.e. probability) became 1 or nearly 1 .

A run on a Pentium 5 machine running one processor with the default settings took 56 seconds. It was estimated from runs with reduced numbers of compounds and variables using the companion program FLIPALL, which tries all of the orientation combinations that an exhaustive evaluation of all possible regressions for the complete data set would take $4 \times 10^{18}$ years for the full data set with this hardware.

The randomisation test that we carried out is essentially that recommended by Topliss et al. Because the matrix of independent variables is preserved it is free from objections related to changes in colinearity that apply to complete randomisation. 


\section{Comparison with other QSAR studies}

Duchowicz et al. [15] performed regression studies on the same set of compounds using methods such as MLR and ANN where three compounds were considered as outliers. The highest $\mathrm{R}^{2}$ and $\mathrm{S}$ values they obtained are 0.94 and 0.01 , respectively.

Ursu et al [26] performed principal components - stepwise regression analysis on 68 compounds and obtained $\mathrm{R}^{2}$ of 0.96 and $\mathrm{S}$ of 0.01 . Both Ursu et al. in [26] and Duchowicz et al in [15] have chosen their descriptors from a very large pool of descriptors leaving much scope for chance correlations of the kind described by Topliss et al. [27, 28]. Another drawback of these studies is that their descriptors had no clearly understandable physical relationship to pharmacological activity.

Yalcin et al [16] performed stepwise regression analysis on a set of 61 compounds using indicator variables, and other variables that are similar to the descriptors we used in this study. Yalcin obtained an $\mathrm{R}^{2}$ of 0.98 , $\mathrm{S}$ of 0.03 and $\mathrm{Q}^{2}$ of 0.67 while we obtained $\mathrm{R}^{2}$ of 0.86 , $\mathrm{S}$ of 0.09 and $\mathrm{Q}^{2}$ of 0.82 . However, as was described above, their results are overfitted as a result of the lack of accuracy of the data that was inherent in the experimental technique used to obtain it. 
However, Yalcin stated that holding a pyridine ring in the bicyclic system is important for the heterocyclic fused system while substituting position $\mathrm{Z}$ with a methylene group as a bridge element between the fused heterocyclic ring system and phenyl ring in this set of molecules providing two fold improved potency against C. albicans and gives higher potency for the antifungal activity, which is in agreement with our results. Yalcin et al [16] found that having a nitro group at position R2 in the bicyclic nucleus while position R1 was found more significant than the positions R and R2 for the screened antifungal activity while we found that both positions are immaterial to the presence of the nitro group.

\section{Conclusion}

We have accounted for as much of the variance in the data set as is possible within the limits set by the experimental error, by assuming that there is no systematic global preference for either of the two possible orientations of the fused ring system. However, except for $\mathrm{NH}_{2}$ over $\mathrm{H}$, there was highly significant preference for the individual R1 versus R2 positions for all substituents. A pyridine ring is more favourable than benzene as the 6-membered ring, for high activity, but thiazole is unfavourable as the 5-membered ring relative to imidazole or oxazole. Methylene is the spacer $\mathrm{W}$ leading to the highest activity.

We have used indicator variables, which account for identity of substituent without any assumptions about the physical origin of their effect, and the simple Hansch-type variables lipophilicity and volume of substituent. Duchowicz et al. [15] employed topological indices selected from a very large pool, leaving much scope for chance correlations of the kind described by Topliss et al. [27, 28], and not having clearly 
understandable physical relationship to pharmacological activity. Unlike previously reported results for this data set our fits do not exceed the limitations set by the nature of the data itself.

A test of the predictive ability of our equations, was achieved as in previous studies [24], with a high level of statistical significance. The relatively low accuracy of the present data set precludes such a test here having practical utility.

\section{Note:}

${ }^{\mathrm{a} C l a r e, ~ B . W . ~(2008) ~ M a r t h a . z i p, ~ a v a i l a b l e ~ f r e e ~ o f ~ c h a r g e ~ f r o m ~ t h e ~ s i t e: ~}$

http://mirrors.uwa.edu.au/mirrors/weboffice/martha/

\section{References:}

1. St-Georgiev, V., Current Drug Targets, 1 (2000) 261.

2. Meyers, F.H., Jawetz, E.,Goldfien, A.Review of Medical Pharmacology.; Lange Medical Pub; 1976.

3. Yalcin, I., Oren, I., Temiz, O.,Sener, E.A., Acta Biochim. Pol., 47 (2000) 481.

4. Rees, J.R., Pinner, R.W.,Hajjeh, R.A., Clin. Infect. Dis., 27 (1998) 1138.

5. Polak, A., Mycoses, 42 (1999) 355.

6. Fostel, J.M.,Lartey, P.A., Drug Discovery Today, 5 (2000) 25.

7. Tafi, A., Costi, R., Botta, M., Di Santo, R., Corelli, F., Massa, S., Ciacci, A., Manetti, F.,Artico, M., Journal of Medicinal Chemistry, 45 (2002) 2720.

8. Chan, J.H., Hong, J.S., Kuyper, L.F., Baccanari, D.P., Joyner, S.S., Tansik, R.L., Boytos, C.M.,Rudolph, S.K., Journal of Medicinal Chemistry, 38 (1995) 3608.

9. Elnima, E.I., Zubair, M.U.,Al-Badr, A.A., Antimicrob. Agents Chemother., 19 (1981) 29. 
10. Goker, H., Kus, C., Boykin, D.W., Yildizc, S.,Altanlar, N., Bioorganic \& Medicinal Chemistry, 10 (2002) 2589-2596.

11. Yildiz-Oren, I., Yalcin, I., Aki-Sener, E.,Ucarturk, N., European Journal of Medicinal Chemistry, 39 (2004) 291.

12. Garci'a-Domenech, R., Ri'os-Santamarina, I., Catala' , A., Calabuig, C., del Castillo, L.,Ga'lvez, J., THEOCHEM, 624 (2003) 97.

13. Hasegawa, K., Deushi, T., Yaegashi, O., Miyashita, Y.,Sasaki, S., European Journal of Medicinal Chemistry, 30 (1995) 569.

14. Mghazli, S., Jaouad, A., Mansour, M., Villemin, D.,Cherqaoui, D., Chemosphere, $43(2001)$

15. Duchowicz, P.R., Vitale, M.G., Castro, E.A., Fernandez, M.,Caballero, J., Bioorganic \& Medicinal Chemistry, 15 (2007) 2680-2689.

16. Yalcìn, I., Ören, I., Temiz, Ö.,Akì Sener, E., Acta Biochimica Polonica, 47 (2000) 481.

17. Clare, B.W., J. Comput.-Aided Mol. Des., 16 (2002) 611.

18. Clare, B.W.,Supuran, C.T., Bioorg. Med. Chem., 13 (2005) 2197.

19. Deeb, O., Alfalah, S.,Clare, B.W., Journal of Enzyme Inhibition and Medicinal Chemistry, 22 (2006) 277.

20. Deeb, O.,Clare, B.W., Chemical Biology and Drug Design, 70 (2007) 437.

21. Hyperchem,6.0:Hypercube Inc,1115 NW 4th Street, Gainesville, Florida 326014256 U.S.A

22. Stewart, J.J.P., Q.C.P.E. Bull., 10 (1990) 86.

23. MOPAC 93,Fujitsu Ltd.,Tokyo, Japan

24. Clare, B.W.,Supuran, C.T., Journal of Chemical Information and Modeling, 45 (2005) 1385. 
25. Kishida, K.,Manabe, R., Med. J. Osaka Univ, 30 (1980) 95.

26. Ursu, O., Costescu, A.,Diudea, M.V., Croatica Chemica Acta, 79 (2006) 483.

27. Topliss, J.G.,Costello, R.J., J. Med. Chem., 15 (1972) 1066.

28. Topliss, J.G.,Edwards, R.J., J. Med. Chem., 22 (1979) 1238.

\section{Supplementary Material:}

The following supplementary material is available for this article:

Table S1. This material includes the different descriptors used in this study. 


\section{Captions for Figures:}

Fig. 1 Structure and the symmetry of the compounds considered in this study

Fig. 2 Correlation of observed p MIC versus estimated

Table 1. Structure and in vitro antifungal activities against Candida Albicans.

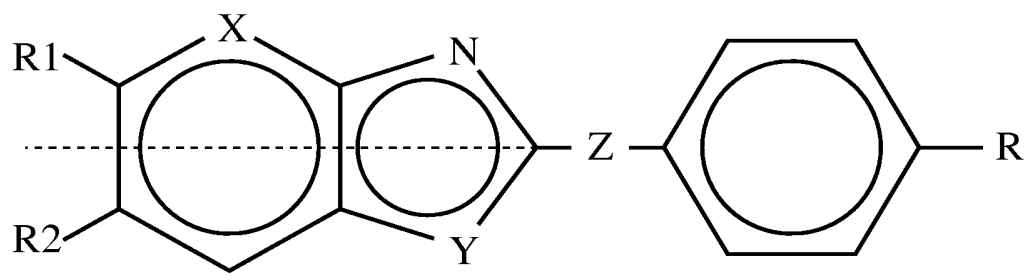

\begin{tabular}{|c|c|c|c|c|c|c|c|}
\hline \multicolumn{2}{|c|}{ Compound X } & \multirow{2}{*}{$\begin{array}{l}\mathbf{Y} \\
\mathrm{O}\end{array}$} & \multirow{2}{*}{$\begin{array}{l}\mathbf{Z} \\
\text { - }^{*}\end{array}$} & \multirow{2}{*}{$\begin{array}{l}\mathbf{R} \\
\mathrm{H}\end{array}$} & \multirow{2}{*}{$\begin{array}{l}\mathbf{R 1} \\
\mathrm{H}\end{array}$} & \multirow{2}{*}{$\begin{array}{l}\mathbf{R 2} \\
\mathrm{H}\end{array}$} & \multirow{2}{*}{$\begin{array}{l}\mathbf{p} M I C[\mathrm{M}] \\
3.892\end{array}$} \\
\hline 1 & $\mathrm{CH}$ & & & & & & \\
\hline 2 & $\mathrm{CH}$ & $\mathrm{O}$ & $-^{*}$ & $\mathrm{C}\left(\mathrm{CH}_{3}\right)_{3}$ & $\mathrm{H}$ & $\mathrm{H}$ & 4.001 \\
\hline 3 & $\mathrm{CH}$ & $\mathrm{O}$ & - $^{*}$ & $\mathrm{NH}_{2}$ & $\mathrm{H}$ & $\mathrm{H}$ & 3.924 \\
\hline 4 & $\mathrm{CH}$ & $\mathrm{O}$ & $-^{*}$ & \multicolumn{2}{|c|}{$\mathrm{NHCOCH}_{3} \mathrm{Cl}$} & $\mathrm{H}$ & 4.059 \\
\hline 5 & $\mathrm{CH}$ & $\mathrm{O}$ & $-^{*}$ & $\mathrm{Cl}$ & $\mathrm{Cl}$ & $\mathrm{H}$ & 4.024 \\
\hline 6 & $\mathrm{CH}$ & $\mathrm{O}$ & $-^{*}$ & $\mathrm{NO}_{2}$ & $\mathrm{Cl}$ & $\mathrm{H}$ & 4.040 \\
\hline 7 & $\mathrm{CH}$ & $\mathrm{O}$ & $-^{*}$ & $\mathrm{H}$ & $\mathrm{NO}_{2}$ & $\mathrm{H}$ & 4.282 \\
\hline 8 & $\mathrm{CH}$ & $\mathrm{O}$ & $-^{*}$ & $\mathrm{CH}_{3}$ & $\mathrm{NO}_{2}$ & $\mathrm{H}$ & 4.308 \\
\hline 9 & $\mathrm{CH}$ & $\mathrm{O}$ & $-^{*}$ & $\mathrm{C}\left(\mathrm{CH}_{3}\right)_{3}$ & $\mathrm{NO}_{2}$ & $\mathrm{H}$ & 4.375 \\
\hline 10 & $\mathrm{CH}$ & $\mathrm{O}$ & - $^{*}$ & $\mathrm{NH}_{2}$ & $\mathrm{NO}_{2}$ & $\mathrm{H}$ & 4.310 \\
\hline 11 & $\mathrm{CH}$ & $\mathrm{O}$ & $-^{*}$ & $\mathrm{Cl}$ & $\mathrm{NO}_{2}$ & $\mathrm{H}$ & 4.342 \\
\hline 12 & $\mathrm{CH}$ & $\mathrm{O}$ & $-^{*}$ & $\mathrm{Br}$ & $\mathrm{NO}_{2}$ & $\mathrm{H}$ & 4.406 \\
\hline 13 & $\mathrm{CH}$ & $\mathrm{O}$ & $-^{*}$ & $\mathrm{C}_{2} \mathrm{H}_{5}$ & $\mathrm{NH}_{2}$ & $\mathrm{H}$ & 3.979 \\
\hline 14 & $\mathrm{CH}$ & $\mathrm{O}$ & - $^{*}$ & $\mathrm{~F}$ & $\mathrm{NH}_{2}$ & $\mathrm{H}$ & 3.960 \\
\hline
\end{tabular}




\begin{tabular}{|c|c|c|c|c|c|c|c|}
\hline 15 & $\mathrm{CH}$ & $\mathrm{O}$ & $-^{*}$ & $\mathrm{~N}\left(\mathrm{CH}_{3}\right)_{2}$ & $\mathrm{NH}_{2}$ & $\mathrm{H}$ & 4.005 \\
\hline 16 & $\mathrm{CH}$ & $\mathrm{O}$ & $-^{*}$ & $\mathrm{CH}_{3}$ & $\mathrm{CH}_{3}$ & $\mathrm{H}$ & 3.950 \\
\hline 17 & $\mathrm{CH}$ & $\mathrm{O}$ & - $^{*}$ & $\mathrm{C}_{2} \mathrm{H}_{5}$ & $\mathrm{CH}_{3}$ & $\mathrm{H}$ & 3.977 \\
\hline 18 & $\mathrm{CH}$ & $\mathrm{O}$ & $-^{*}$ & $\mathrm{OCH}_{3}$ & $\mathrm{CH}_{3}$ & $\mathrm{H}$ & 3.980 \\
\hline 19 & $\mathrm{CH}$ & $\mathrm{O}$ & $-^{*}$ & $\mathrm{~F}$ & $\mathrm{CH}_{3}$ & $\mathrm{H}$ & 3.958 \\
\hline 20 & $\mathrm{CH}$ & $\mathrm{O}$ & $-^{*}$ & \multicolumn{2}{|c|}{$\mathrm{NHCOCH}_{3} \mathrm{CH}_{3}$} & $\mathrm{H}$ & 4.027 \\
\hline 21 & $\mathrm{CH}$ & $\mathrm{O}$ & $-^{*}$ & $\mathrm{NHCH}_{3}$ & $\mathrm{CH}_{3}$ & $\mathrm{H}$ & 3.979 \\
\hline 22 & $\mathrm{CH}$ & $\mathrm{O}$ & $-^{*}$ & $\mathrm{~N}\left(\mathrm{CH}_{3}\right)_{2}$ & $\mathrm{CH}_{3}$ & $\mathrm{H}$ & 4.004 \\
\hline 23 & $\mathrm{~N}$ & $\mathrm{O}$ & $-^{*}$ & $\mathrm{CH}_{3}$ & $\mathrm{H}$ & $\mathrm{H}$ & 4.225 \\
\hline 24 & $\mathrm{~N}$ & $\mathrm{O}$ & $-^{*}$ & $\mathrm{C}_{2} \mathrm{H}_{5}$ & $\mathrm{H}$ & $\mathrm{H}$ & 4.253 \\
\hline 25 & $\mathrm{~N}$ & $\mathrm{O}$ & $-^{*}$ & $\mathrm{OCH}_{3}$ & $\mathrm{H}$ & $\mathrm{H}$ & 4.257 \\
\hline 26 & $\mathrm{~N}$ & $\mathrm{O}$ & $-^{*}$ & $\mathrm{OC}_{2} \mathrm{H}_{5}$ & $\mathrm{H}$ & $\mathrm{H}$ & 4.283 \\
\hline 27 & $\mathrm{~N}$ & $\mathrm{O}$ & $-^{*}$ & $\mathrm{NH}_{2}$ & $\mathrm{H}$ & $\mathrm{H}$ & 4.227 \\
\hline 28 & $\mathrm{~N}$ & $\mathrm{O}$ & $-^{*}$ & $\mathrm{NO}_{2}$ & $\mathrm{H}$ & $\mathrm{H}$ & 4.285 \\
\hline 29 & $\mathrm{CH}$ & $\mathrm{O}$ & $-^{*}$ & $\mathrm{Br}$ & $\mathrm{NH}_{2}$ & $\mathrm{H}$ & 4.110 \\
\hline 30 & $\mathrm{CH}$ & $\mathrm{O}$ & $\mathrm{CH}_{2}$ & $\mathrm{OCH}_{3}$ & $\mathrm{H}$ & $\mathrm{H}$ & 4.282 \\
\hline 31 & $\mathrm{CH}$ & $\mathrm{O}$ & $\mathrm{CH}_{2}$ & $\mathrm{NO}_{2}$ & $\mathrm{H}$ & $\mathrm{H}$ & 4.308 \\
\hline 32 & $\mathrm{CH}$ & $\mathrm{O}$ & $\mathrm{CH}_{2}$ & $\mathrm{H}$ & $\mathrm{Cl}$ & $\mathrm{H}$ & 4.290 \\
\hline 33 & $\mathrm{CH}$ & $\mathrm{O}$ & $\mathrm{CH}_{2}$ & $\mathrm{OCH}_{3}$ & $\mathrm{Cl}$ & $\mathrm{H}$ & 4.340 \\
\hline 34 & $\mathrm{CH}$ & $\mathrm{O}$ & $\mathrm{CH}_{2}$ & $\mathrm{Br}$ & $\mathrm{Cl}$ & $\mathrm{H}$ & 4.410 \\
\hline 35 & $\mathrm{CH}$ & $\mathrm{O}$ & $\mathrm{CH}_{2}$ & $\mathrm{NO}_{2}$ & $\mathrm{Cl}$ & $\mathrm{H}$ & 4.363 \\
\hline 36 & $\mathrm{CH}$ & $\mathrm{O}$ & $\mathrm{CH}_{2}$ & $\mathrm{H}$ & $\mathrm{NO}_{2}$ & $\mathrm{H}$ & 4.609 \\
\hline 37 & $\mathrm{CH}$ & $\mathrm{O}$ & $\mathrm{CH}_{2}$ & $\mathrm{OCH}_{3}$ & $\mathrm{NO}_{2}$ & $\mathrm{H}$ & 4.657 \\
\hline 38 & $\mathrm{CH}$ & $\mathrm{O}$ & $\mathrm{CH}_{2}$ & $\mathrm{Br}$ & $\mathrm{NO}_{2}$ & $\mathrm{H}$ & 4.725 \\
\hline
\end{tabular}




\begin{tabular}{|c|c|c|c|c|c|c|c|}
\hline 39 & $\mathrm{CH}$ & $\mathrm{O}$ & $\mathrm{CH}_{2}$ & $\mathrm{Cl}$ & $\mathrm{NO}_{2}$ & $\mathrm{H}$ & 4.664 \\
\hline 40 & $\mathrm{CH}$ & $\mathrm{O}$ & $\mathrm{CH}_{2} \mathrm{O}$ & $\mathrm{H}$ & $\mathrm{H}$ & $\mathrm{NO}_{2}$ & 3.732 \\
\hline 41 & $\mathrm{CH}$ & $\mathrm{O}$ & $\mathrm{CH}_{2} \mathrm{O}$ & $\mathrm{Cl}$ & $\mathrm{Cl}$ & $\mathrm{NO}_{2}$ & 3.831 \\
\hline 42 & $\mathrm{CH}$ & $\mathrm{O}$ & $\mathrm{CH}_{2} \mathrm{~S}$ & $\mathrm{H}$ & $\mathrm{NO}_{2}$ & $\mathrm{H}$ & 4.359 \\
\hline 43 & $\mathrm{CH}$ & $\mathrm{O}$ & $\mathrm{CH}_{2} \mathrm{~S}$ & $\mathrm{H}$ & $\mathrm{CH}_{3}$ & $\mathrm{H}$ & 4.009 \\
\hline 44 & $\mathrm{~N}$ & $\mathrm{O}$ & $\mathrm{CH}_{2} \mathrm{O}$ & $\mathrm{H}$ & $\mathrm{H}$ & $\mathrm{H}$ & 4.26 \\
\hline 45 & $\mathrm{~N}$ & $\mathrm{O}$ & $\mathrm{CH}_{2} \mathrm{O}$ & $\mathrm{Cl}$ & $\mathrm{H}$ & $\mathrm{H}$ & 4.319 \\
\hline 46 & $\mathrm{CH}$ & $\mathrm{NH}$ & $\mathrm{CH}_{2} \mathrm{O}$ & $\mathrm{Cl}$ & $\mathrm{CH}_{3}$ & $\mathrm{H}$ & 4.037 \\
\hline 47 & $\mathrm{CH}$ & $\mathrm{NH}$ & $\mathrm{CH}_{2} \mathrm{~S}$ & $\mathrm{H}$ & $\mathrm{NO}_{2}$ & $\mathrm{H}$ & 4.358 \\
\hline 48 & $\mathrm{CH}$ & $\mathrm{NH}$ & $\mathrm{CH}_{2} \mathrm{~S}$ & $\mathrm{H}$ & $\mathrm{CH}_{3}$ & $\mathrm{H}$ & 4.009 \\
\hline 49 & $\mathrm{CH}$ & $\mathrm{O}$ & $\mathrm{CH}_{2} \mathrm{O}$ & $\mathrm{H}$ & \multicolumn{2}{|c|}{$\mathrm{COOCH}_{3} \mathrm{H}$} & 4.054 \\
\hline 50 & $\mathrm{CH}$ & $\mathrm{O}$ & $\mathrm{CH}_{2} \mathrm{O}$ & $\mathrm{Cl}$ & \multicolumn{2}{|c|}{$\mathrm{COOCH}_{3} \mathrm{H}$} & 4.104 \\
\hline 51 & $\mathrm{CH}$ & $\mathrm{NH}$ & $\mathrm{CH}_{2} \mathrm{O}$ & $\mathrm{Cl}$ & \multicolumn{2}{|c|}{$\mathrm{COOCH}_{3} \mathrm{H}$} & 4.102 \\
\hline 52 & $\mathrm{CH}$ & $\mathrm{NH}$ & $\mathrm{CH}_{2} \mathrm{~S}$ & $\mathrm{H}$ & \multicolumn{2}{|c|}{$\mathrm{COOCH}_{3} \mathrm{H}$} & 4.076 \\
\hline 53 & $\mathrm{CH}$ & $\mathrm{O}$ & $\mathrm{C}_{2} \mathrm{H}_{4}$ & $\mathrm{H}$ & $\mathrm{NO}_{2}$ & $\mathrm{H}$ & 4.331 \\
\hline 54 & $\mathrm{~N}$ & $\mathrm{O}$ & $\mathrm{C}_{2} \mathrm{H}_{4}$ & $\mathrm{H}$ & $\mathrm{H}$ & $\mathrm{H}$ & 4.253 \\
\hline 55 & $\mathrm{CH}$ & $\mathrm{NH}$ & $\mathrm{CH}_{2} \mathrm{O}$ & $\mathrm{H}$ & $\mathrm{NO}_{2}$ & $\mathrm{H}$ & 4.283 \\
\hline 56 & $\mathrm{CH}$ & $\mathrm{NH}$ & $\mathrm{CH}_{2} \mathrm{O}$ & $\mathrm{Cl}$ & $\mathrm{H}$ & $\mathrm{H}$ & 4.015 \\
\hline 57 & $\mathrm{CH}$ & $\mathrm{NH}$ & $\mathrm{CH}_{2} \mathrm{~S}$ & $\mathrm{H}$ & $\mathrm{Cl}$ & $\mathrm{H}$ & 4.041 \\
\hline 58 & $\mathrm{CH}$ & $\mathrm{NH}$ & $\mathrm{C}_{2} \mathrm{H}_{4}$ & $\mathrm{H}$ & $\mathrm{H}$ & $\mathrm{H}$ & 4.078 \\
\hline 59 & $\mathrm{CH}$ & $\mathrm{O}$ & $\mathrm{CH}_{2} \mathrm{O}$ & $\mathrm{H}$ & $\mathrm{H}$ & $\mathrm{CH}_{3}$ & 3.981 \\
\hline 60 & $\mathrm{CH}$ & $\mathrm{O}$ & $\mathrm{CH}_{2} \mathrm{O}$ & $\mathrm{Cl}$ & $\mathrm{Cl}$ & $\mathrm{H}$ & 4.071 \\
\hline 61 & $\mathrm{CH}$ & $\mathrm{O}$ & $\mathrm{CH}_{2} \mathrm{O}$ & $\mathrm{Cl}$ & $\mathrm{CH}_{3}$ & $\mathrm{H}$ & 3.738 \\
\hline 62 & $\mathrm{CH}$ & $\mathrm{O}$ & $\mathrm{CH}_{2} \mathrm{O}$ & $\mathrm{Cl}$ & $\mathrm{H}$ & $\mathrm{CH}_{3}$ & 3.738 \\
\hline
\end{tabular}




\begin{tabular}{|c|c|c|c|c|c|c|c|}
\hline 63 & $\mathrm{CH}$ & $\mathrm{O}$ & $\mathrm{CH}_{2} \mathrm{O}$ & $\mathrm{H}$ & $\mathrm{Cl}$ & $\mathrm{H}$ & 4.344 \\
\hline 64 & $\mathrm{CH}$ & $\mathrm{O}$ & $\mathrm{CH}_{2} \mathrm{~S}$ & $\mathrm{H}$ & $\mathrm{H}$ & $\mathrm{CH}_{3}$ & 4.009 \\
\hline 65 & $\mathrm{CH}$ & $\mathrm{O}$ & $\mathrm{CH}_{2} \mathrm{O}$ & $\mathrm{H}$ & $\mathrm{H}$ & $\mathrm{H}$ & 3.955 \\
\hline 66 & $\mathrm{CH}$ & $\mathrm{O}$ & $\mathrm{CH}_{2} \mathrm{O}$ & $\mathrm{H}$ & $\mathrm{NO}_{2}$ & $\mathrm{H}$ & 4.034 \\
\hline 67 & $\mathrm{CH}$ & $\mathrm{O}$ & $\mathrm{CH}_{2} \mathrm{O}$ & $\mathrm{H}$ & $\mathrm{Cl}$ & $\mathrm{H}$ & 4.017 \\
\hline 68 & $\mathrm{CH}$ & $\mathrm{O}$ & $\mathrm{CH}_{2} \mathrm{O}$ & $\mathrm{Cl}$ & $\mathrm{NO}_{2}$ & $\mathrm{H}$ & 4.086 \\
\hline 69 & $\mathrm{CH}$ & $\mathrm{O}$ & $\mathrm{CH}_{2} \mathrm{~S}$ & $\mathrm{H}$ & $\mathrm{H}$ & $\mathrm{H}$ & 4.286 \\
\hline 70 & $\mathrm{CH}$ & $\mathrm{O}$ & $\mathrm{CH}_{2} \mathrm{~S}$ & $\mathrm{H}$ & $\mathrm{Cl}$ & $\mathrm{NO}_{2}$ & 4.409 \\
\hline 71 & $\mathrm{CH}$ & $\mathrm{O}$ & $\mathrm{CH}_{2} \mathrm{~S}$ & $\mathrm{H}$ & \multicolumn{2}{|c|}{$\mathrm{COOCH}_{3} \mathrm{H}$} & 4.379 \\
\hline 72 & $\mathrm{CH}$ & $\mathrm{S}$ & $\mathrm{CH}_{2} \mathrm{O}$ & $\mathrm{H}$ & $\mathrm{H}$ & $\mathrm{H}$ & 3.684 \\
\hline 73 & $\mathrm{CH}$ & $\mathrm{S}$ & $\mathrm{CH}_{2} \mathrm{O}$ & $\mathrm{Cl}$ & $\mathrm{H}$ & $\mathrm{H}$ & 3.742 \\
\hline 74 & $\mathrm{CH}$ & $\mathrm{S}$ & $\mathrm{CH}_{2} \mathrm{~S}$ & $\mathrm{H}$ & $\mathrm{H}$ & $\mathrm{H}$ & 4.013 \\
\hline 75 & $\mathrm{CH}$ & $\mathrm{NH}$ & $\mathrm{CH}_{2} \mathrm{O}$ & $\mathrm{H}$ & $\mathrm{Cl}$ & $\mathrm{H}$ & 4.316 \\
\hline 76 & $\mathrm{CH}$ & $\mathrm{NH}$ & $\mathrm{CH}_{2} \mathrm{O}$ & $\mathrm{H}$ & \multicolumn{2}{|c|}{$\mathrm{COOCH}_{3} \mathrm{H}$} & 4.053 \\
\hline 77 & $\mathrm{CH}$ & $\mathrm{NH}$ & $\mathrm{CH}_{2} \mathrm{O}$ & $\mathrm{Cl}$ & $\mathrm{Cl}$ & $\mathrm{H}$ & 4.370 \\
\hline 78 & $\mathrm{CH}$ & $\mathrm{NH}$ & $\mathrm{CH}_{2} \mathrm{NH}$ & $\mathrm{H}$ & $\mathrm{H}$ & $\mathrm{H}$ & 3.951 \\
\hline 79 & $\mathrm{CH}$ & $\mathrm{NH}$ & $\mathrm{CH}_{2} \mathrm{NH}$ & $\mathrm{H}$ & $\mathrm{CH}_{3}$ & $\mathrm{H}$ & 3.977 \\
\hline 80 & $\mathrm{CH}$ & $\mathrm{NH}$ & $\mathrm{C}_{2} \mathrm{H}_{4}$ & $\mathrm{H}$ & $\mathrm{Cl}$ & $\mathrm{H}$ & 4.012 \\
\hline 81 & $\mathrm{CH}$ & $\mathrm{O}$ & $-^{*}$ & $\mathrm{NHCH}_{3}$ & $\mathrm{H}$ & $\mathrm{H}$ & 3.952 \\
\hline 82 & $\mathrm{CH}$ & $\mathrm{O}$ & $-^{*}$ & $\mathrm{C}_{2} \mathrm{H}_{5}$ & $\mathrm{Cl}$ & $\mathrm{H}$ & 4.013 \\
\hline 83 & $\mathrm{CH}$ & $\mathrm{O}$ & $-^{*}$ & $\mathrm{NHCH}_{3}$ & $\mathrm{Cl}$ & $\mathrm{H}$ & 4.025 \\
\hline 84 & $\mathrm{CH}$ & $\mathrm{O}$ & $\mathrm{CH}_{2}$ & $\mathrm{H}$ & $\mathrm{H}$ & $\mathrm{H}$ & 4.223 \\
\hline 85 & $\mathrm{CH}$ & $\mathrm{O}$ & $\mathrm{CH}_{2}$ & $\mathrm{Cl}$ & $\mathrm{H}$ & $\mathrm{H}$ & 4.290 \\
\hline 86 & $\mathrm{CH}$ & $\mathrm{O}$ & $\mathrm{CH}_{2}$ & $\mathrm{NO}_{2}$ & $\mathrm{NO}_{2}$ & $\mathrm{H}$ & 4.680 \\
\hline
\end{tabular}




$\begin{array}{rccccccc}87 & \mathrm{CH} & \mathrm{O} & \mathrm{CH}_{2} & \mathrm{Br} & \mathrm{H} & \mathrm{H} & 4.360 \\ 88 & \mathrm{CH} & \mathrm{O} & \mathrm{CH}_{2} \mathrm{O} & \mathrm{H} & \mathrm{CH}_{3} & \mathrm{H} & 3.980 \\ 89 & \mathrm{CH} & \mathrm{O} & \mathrm{CH}_{2} \mathrm{O} & \mathrm{H} & \mathrm{Cl} & \mathrm{NO}_{2} & 3.785 \\ 90 & \mathrm{CH} & \mathrm{O} & \mathrm{CH}_{2} \mathrm{O} & \mathrm{Cl} & \mathrm{H} & \mathrm{H} & 4.016 \\ 91 & \mathrm{CH} & \mathrm{O} & \mathrm{CH}_{2} \mathrm{O} & \mathrm{Cl} & \mathrm{H} & \mathrm{NO}_{2} & 3.785 \\ 92 & \mathrm{CH} & \mathrm{O} & \mathrm{CH}_{2} \mathrm{~S} & \mathrm{H} & \mathrm{H} & \mathrm{NO}_{2} & 4.360 \\ 93 & \mathrm{CH} & \mathrm{NH} & \mathrm{CH}_{2} \mathrm{O} & \mathrm{H} & \mathrm{H} & \mathrm{H} & 3.953 \\ 94 & \mathrm{CH} & \mathrm{NH} & \mathrm{CH}_{2} \mathrm{O} & \mathrm{H} & \mathrm{CH}_{3} & \mathrm{H} & 3.979 \\ 95 & \mathrm{CH} & \mathrm{NH} & \mathrm{CH}_{2} \mathrm{~S} & \mathrm{H} & \mathrm{H} & \mathrm{H} & 4.284 \\ 96 & \mathrm{CH} & \mathrm{NH} & \mathrm{C}_{2} \mathrm{H}_{4} & \mathrm{H} & \mathrm{CH}_{3} & \mathrm{H} & 4.277\end{array}$

- The dash “- “ indicates that there is no spacer between the two aromatic rings.

Reprinted from Bioorg. Med. Chem. Vol. 15, by P.R. Duchowicz, M.G.

Vitale, E.A. Castro, M. Fernandez and J. Caballero, QSAR Analysis of

Heterocyclic Antifungals pages 2680-2689, copyright 2007, with permission from Elsevier.

Table 2. Key for variables used in this study.

\begin{tabular}{ll}
\hline Variable symbol & Explanation \\
\hline$\Pi$ & The sum of $\mathrm{P}_{\mathrm{xx}}, \mathrm{P}_{\mathrm{yy}}$ and $\mathrm{P}_{\mathrm{zz}}$ calculated by MOPAC 6 \\
LDIG & Local dipole index: (Mean absolute difference of charge, \\
& calculated over all bonded pairs of atoms) \\
& Solvation energy calculated by MOPAC93, kcal
\end{tabular}




$\begin{array}{ll}\mathrm{RV} & \text { Volume of } \mathrm{R}\left(\AA^{3}\right) \text { calculated by Hyperchem } \\ \mathrm{R} \pi & \text { Lipophilicity of } \mathrm{R} \text { calculated by Hyperchem } \\ \mathrm{R} 1 \mathrm{~V} & \text { Volume of } \mathrm{R} 1\left(\AA^{3}\right) \text { calculated by Hyperchem } \\ \mathrm{R} 1 \pi & \text { Volume of } \mathrm{R} 2\left(\AA^{3}\right) \text { calculated by Hyperchem } \\ \mathrm{R} 2 \mathrm{~V} & \text { Lipophilicity of } \mathrm{R} 2 \text { calculated by Hyperchem } \\ \mathrm{R} 2 \pi & 1 \text { if } \mathrm{X} \text { is } \mathrm{N}, 0 \text { otherwise } \\ \mathrm{I}\left(\mathrm{Pyr}^{2}\right) & 1 \text { if } \mathrm{Y} \text { is } \mathrm{NH}^{2} 0 \text { otherwise } \\ \mathrm{I}\left(\mathrm{Imi}^{2}\right) & 1 \text { if } \mathrm{Y} \text { is } \mathrm{S}, 0 \text { otherwise } \\ \mathrm{I}(\mathrm{Thi}) & 1 \text { if } \mathrm{Z} \text { is } \mathrm{CH}_{2}, 0 \text { otherwise } \\ \mathrm{I}\left(\mathrm{CH}_{2}\right) & 1 \text { if } \mathrm{Z} \text { is } \mathrm{CH}_{2} \mathrm{O}, 0 \text { otherwise } \\ \mathrm{I}\left(\mathrm{CH}_{2} \mathrm{O}\right) & 1 \text { if } \mathrm{Z} \text { is } \mathrm{CH}_{2} \mathrm{~S}, 0 \text { otherwise } \\ \mathrm{I}\left(\mathrm{CH}_{2} \mathrm{~S}\right) & 1 \text { if } \mathrm{Z} \text { is } \mathrm{C}_{2} \mathrm{H}_{4}, 0 \text { otherwise } \\ \mathrm{I}\left(\mathrm{C}_{2} \mathrm{H}_{4}\right) & 1 \text { if } \mathrm{Z} \text { is } \mathrm{CH}_{2} \mathrm{NH}, 0 \text { otherwise } \\ \mathrm{I}\left(\mathrm{CH}_{2} \mathrm{NH}\right) & \end{array}$

Table 3. Flipstep regression results with flipstep without flipping any variables.

\section{Deleted}

\begin{tabular}{lllllll} 
Variable & Coefficient & $\mathbf{t}$ & \multicolumn{2}{c}{ Significance VIF } & \multicolumn{2}{c}{ (Insignificant) } \\
\hline $\mathrm{R} 1 \pi$ & -0.0698 & 8.27 & 0.00000 & 1.06 & $\left.\mathrm{ICH}_{2} \mathrm{O}\right)$ & $\mathrm{R} \pi$ \\
$\mathrm{I}(\mathrm{Pyr})$ & 0.23032 & 5.10 & 0.00000 & 1.04 & $\mathrm{I}\left(\mathrm{CH}_{2} \mathrm{NH}\right)$ & $\mathrm{R} 1 \mathrm{~V}$ \\
$\mathrm{I}(\mathrm{Thi})$ & -0.25424 & 3.39 & 0.00105 & 1.02 & $\mathrm{R} 2 \pi$ & $\mathrm{RV}$ \\
$\mathrm{I}\left(\mathrm{CH}_{2}\right)$ & 0.3411 & 9.00 & 0.00000 & 1.07 & $\mathrm{I}(\mathrm{Imi})$ & $\mathrm{I}\left(\mathrm{C}_{2} \mathrm{H}_{4}\right)$ \\
$\mathrm{I}\left(\mathrm{CH}_{2} \mathrm{~S}\right)$ & 0.15802 & 4.07 & 0.00010 & 1.06 & $\mathrm{R} 2 \mathrm{~V}$ &
\end{tabular}


Table 4. Flipstep regression results for flipping R1V with R2V and R1 $\pi$ with R2 $\pi$.

\section{Deleted}

\begin{tabular}{llllll} 
Variable & Coefficient & t & \multicolumn{2}{l}{ Significance VIF } & (Insignificant) \\
\hline$\Pi$ & 0.00078 & 2.70 & 0.00844 & 1.83 & $\Delta \mathrm{H}_{\mathrm{S}}$ \\
$\mathrm{R} 1 \mathrm{~V}$ & -0.00047 & 1.29 & 0.19990 & 2.20 & $\mathrm{I}\left(\mathrm{C}_{2} \mathrm{H}_{4}\right)$ \\
$\mathrm{R} 1 \pi$ & -0.07136 & 7.90 & 0.00000 & 1.24 & $\mathrm{RV}$ \\
$\mathrm{R} 2 \mathrm{~V}$ & 0.00271 & 4.93 & 0.00000 & 1.88 & $\mathrm{LDIG}$ \\
$\mathrm{R} 2 \pi$ & 0.10119 & 7.92 & 0.00000 & 1.50 & $\mathrm{R} \pi$ \\
$\mathrm{I}(\mathrm{Pyr})$ & 0.27233 & 8.15 & 0.00000 & 1.34 & $\mathrm{I}\left(\mathrm{CH}_{2} \mathrm{NH}\right)$ \\
$\mathrm{I}(\mathrm{Imi})$ & 0.05504 & 2.396 & 0.01879 & 1.19 & $\mathrm{I}\left(\mathrm{CH}_{2} \mathrm{O}\right)$ \\
$\mathrm{I}(\mathrm{Thi})$ & -0.22709 & 4.35 & 0.00004 & 1.17 & \\
$\mathrm{I}\left(\mathrm{CH}_{2}\right)$ & 0.37586 & 13.98 & 0.00000 & 1.27 & \\
$\mathrm{I}\left(\mathrm{CH}_{2} \mathrm{~S}\right)$ & 0.07111 & 2.73 & 0.00767 & 1.12 &
\end{tabular}


Table 5. Observed and estimated pMIC.

\begin{tabular}{|c|c|c|c|c|c|}
\hline Compound & $\mathrm{p} M I C_{\text {observed }}$ & $\mathbf{p} M I C_{\text {predicted }}$ & Compound & $\mathrm{p} M I C_{\text {observed }}$ & $\mathrm{p} M I C_{\text {predicted }}$ \\
\hline 1 & 3.892 & 3.952 & 49 & 4.054 & 4.066 \\
\hline 2 & 4.001 & 4.041 & 50 & 4.104 & 4.035 \\
\hline 3 & 3.924 & 3.992 & 51 & 4.102 & 4.091 \\
\hline 4 & 4.059 & 4.015 & 52 & 4.076 & 4.182 \\
\hline 5 & 4.024 & 3.942 & 53 & 4.331 & 4.264 \\
\hline 6 & 4.040 & 3.966 & 54 & 4.253 & 4.235 \\
\hline 7 & 4.282 & 4.247 & 55 & 4.283 & 4.311 \\
\hline 8 & 4.308 & 4.278 & 56 & 4.015 & 4.055 \\
\hline 9 & 4.375 & 4.338 & 57 & 4.041 & 4.088 \\
\hline 10 & 4.310 & 4.292 & 58 & 4.078 & 4.034 \\
\hline 11 & 4.342 & 4.273 & 59 & 3.981 & 3.927 \\
\hline 12 & 4.406 & 4.281 & 60 & 4.071 & 4.168 \\
\hline 13 & 3.979 & 4.046 & 61 & 3.738 & 3.960 \\
\hline 14 & 3.960 & 4.005 & 62 & 3.738 & 3.947 \\
\hline 15 & 4.005 & 4.092 & 63 & 4.344 & 4.148 \\
\hline 16 & 3.950 & 3.950 & 64 & 4.009 & 4.045 \\
\hline 17 & 3.977 & 3.970 & 65 & 3.955 & 3.959 \\
\hline 18 & 3.980 & 3.970 & 66 & 4.034 & 4.251 \\
\hline 19 & 3.958 & 3.930 & 67 & 4.017 & 3.921 \\
\hline 20 & 4.027 & 4.020 & 68 & 4.086 & 4.270 \\
\hline 21 & 3.979 & 3.989 & 69 & 4.286 & 4.075 \\
\hline 22 & 4.004 & 4.016 & 70 & 4.409 & 4.545 \\
\hline
\end{tabular}




\begin{tabular}{|c|c|c|c|c|c|}
\hline 23 & 4.225 & 4.246 & 71 & 4.379 & 4.431 \\
\hline 24 & 4.253 & 4.266 & 72 & 3.684 & 3.775 \\
\hline 25 & 4.257 & 4.266 & 73 & 3.742 & 3.797 \\
\hline 26 & 4.283 & 4.290 & 74 & 4.013 & 3.867 \\
\hline 27 & 4.227 & 4.257 & 75 & 4.316 & 4.224 \\
\hline 28 & 4.285 & 4.264 & 76 & 4.053 & 4.077 \\
\hline 29 & 4.110 & 4.052 & 77 & 4.370 & 4.246 \\
\hline 30 & 4.282 & 4.362 & 78 & 3.951 & 4.033 \\
\hline 31 & 4.308 & 4.363 & 79 & 3.977 & 3.996 \\
\hline 32 & 4.290 & 4.286 & 80 & 4.012 & 3.997 \\
\hline 33 & 4.340 & 4.327 & 81 & 3.952 & 4.021 \\
\hline 34 & 4.410 & 4.313 & 82 & 4.013 & 3.967 \\
\hline 35 & 4.363 & 4.328 & 83 & 4.025 & 3.988 \\
\hline 36 & 4.609 & 4.617 & 84 & 4.223 & 4.321 \\
\hline 37 & 4.657 & 4.659 & 85 & 4.290 & 4.340 \\
\hline 38 & 4.725 & 4.645 & 86 & 4.680 & 4.655 \\
\hline 39 & 4.664 & 4.638 & 87 & 4.360 & 4.348 \\
\hline 40 & 3.732 & 3.774 & 88 & 3.980 & 3.925 \\
\hline 41 & 3.831 & 3.753 & 89 & 3.785 & 3.735 \\
\hline 42 & 4.359 & 4.283 & 90 & 4.016 & 3.978 \\
\hline 43 & 4.009 & 4.028 & 91 & 3.785 & 3.798 \\
\hline 44 & 4.260 & 4.294 & 92 & 4.360 & 4.356 \\
\hline 45 & 4.319 & 4.243 & 93 & 3.953 & 4.024 \\
\hline 46 & 4.037 & 4.023 & 94 & 3.979 & 3.984 \\
\hline 47 & 4.358 & 4.347 & 95 & 4.284 & 4.125 \\
\hline
\end{tabular}


Table 6. Flip status and significances of the 96 compounds with flipping R1V with R2V and $\mathrm{R} 1 \pi$ with $\mathrm{R} 2 \pi$.

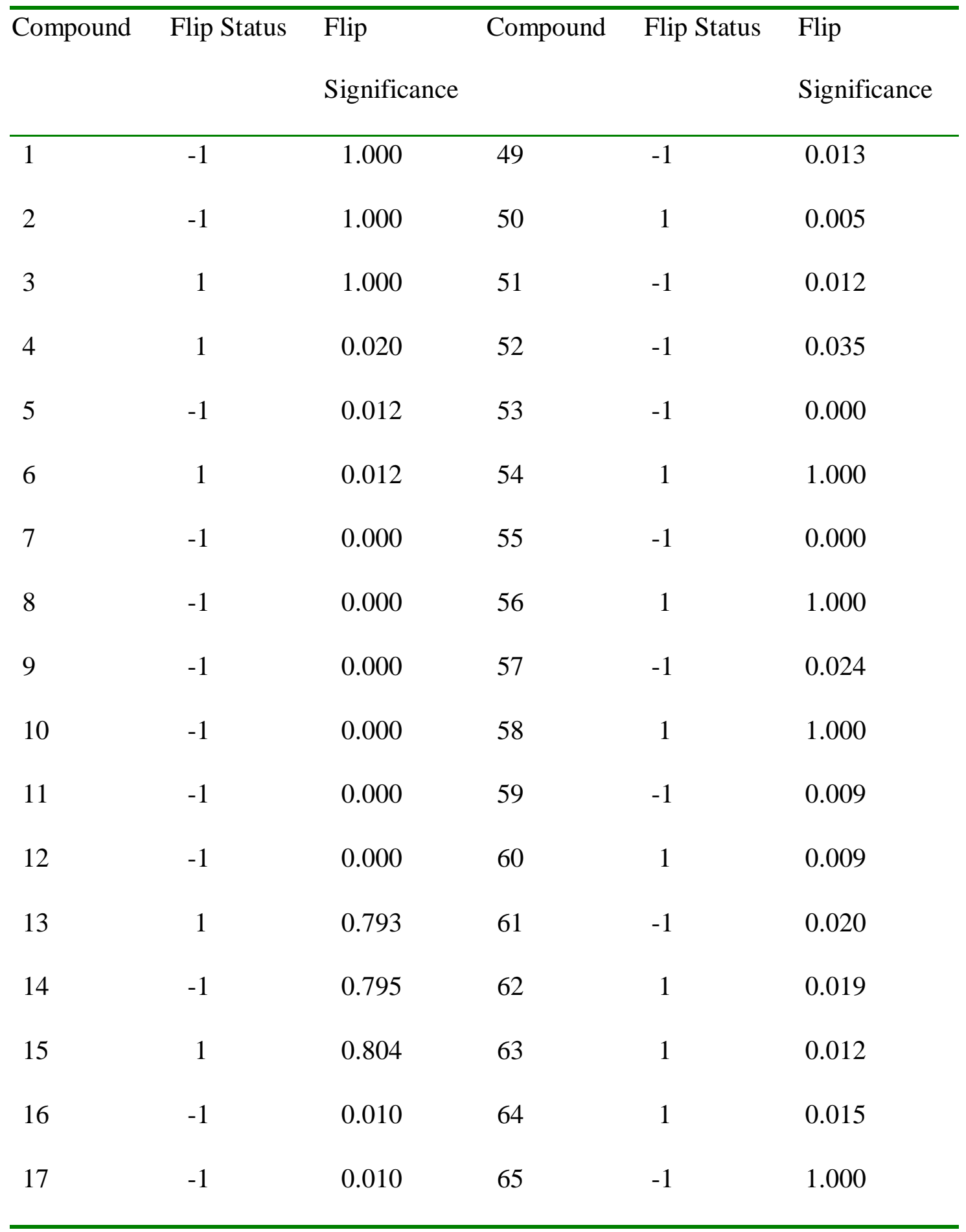




\begin{tabular}{|c|c|c|c|c|c|}
\hline 18 & -1 & 0.010 & 66 & -1 & 0.000 \\
\hline 19 & -1 & 0.010 & 67 & -1 & 0.014 \\
\hline 20 & 1 & 0.016 & 68 & -1 & 0.000 \\
\hline 21 & -1 & 0.011 & 69 & -1 & 1.000 \\
\hline 22 & -1 & 0.016 & 70 & 1 & 0.000 \\
\hline 23 & -1 & 1.000 & 71 & 1 & 0.001 \\
\hline 24 & 1 & 1.000 & 72 & 1 & 1.000 \\
\hline 25 & 1 & 1.000 & 73 & 1 & 1.000 \\
\hline 26 & 1 & 1.000 & 74 & -1 & 1.000 \\
\hline 27 & -1 & 1.000 & 75 & 1 & 0.012 \\
\hline 28 & -1 & 1.000 & 76 & -1 & 0.016 \\
\hline 29 & -1 & 0.805 & 77 & 1 & 0.012 \\
\hline 30 & -1 & 1.000 & 78 & 1 & 1.000 \\
\hline 31 & 1 & 1.000 & 79 & -1 & 0.012 \\
\hline 32 & -1 & 0.023 & 80 & -1 & 0.016 \\
\hline 33 & -1 & 0.021 & 81 & 1 & 1.000 \\
\hline 34 & -1 & 0.017 & 82 & -1 & 0.013 \\
\hline 35 & 1 & 0.021 & 83 & -1 & 0.015 \\
\hline 36 & -1 & 0.000 & 84 & -1 & 1.000 \\
\hline 37 & -1 & 0.000 & 85 & -1 & 1.000 \\
\hline 38 & -1 & 0.000 & 86 & -1 & 0.000 \\
\hline 39 & -1 & 0.000 & 87 & -1 & 1.000 \\
\hline 40 & -1 & 0.000 & 88 & 1 & 0.010 \\
\hline 41 & -1 & 0.000 & 89 & -1 & 0.000 \\
\hline
\end{tabular}




\begin{tabular}{llllll}
\hline 42 & -1 & 0.000 & 90 & 1 & 1.000 \\
43 & -1 & 0.014 & 91 & -1 & 0.000 \\
44 & -1 & 1.000 & 92 & 1 & 0.000 \\
45 & -1 & 1.000 & 93 & 1 & 1.000 \\
46 & -1 & 0.011 & 94 & -1 & 0.013 \\
48 & -1 & 0.000 & 95 & -1 & 1.000 \\
\hline
\end{tabular}

Table 7

Predictions by Flippred from training sets of held-out test sets.

\begin{tabular}{l|lllll}
\hline Run & $R^{2}$ & Prob & Reg. Coef & Training & Variables \\
& & & & \\
& & & & \\
& & & & \\
2 & & & & \\
2 & 0.219 & 0.037 & 0.692 & 76 & 9 \\
3 & 0.450 & 0.0012 & 0.541 & 76 & 10 \\
4 & 0.636 & 0.0057 & 0.412 & 86 & 9 \\
5 & 0.258 & 0.031 & 0.607 & 78 & 9 \\
6 & 0.157 & 0.050 & 0.223 & 71 & 7 \\
7 & 0.008 & 0.642 & 0.072 & 69 & 10 \\
8 & 0.177 & 0.045 & 0.444 & 73 & 12 \\
\hline
\end{tabular}


Table 8

Effect of cooling regime on simulated annealing performance

\begin{tabular}{|c|c|c|c|c|c|c|}
\hline Run & Cycles & Cool Rate & Variables & $F$ & $R^{2}$ & $N^{b}$ \\
\hline \multirow[t]{4}{*}{1} & 2000 & 2 & 10 & 60.73 & 0.8772 & 5 \\
\hline & & & 10 & 60.61 & 0.8770 & 2 \\
\hline & & & 9 & 50.39 & 0.8793 & 2 \\
\hline & & & 12 & 64.43 & 0.8708 & 1 \\
\hline \multirow[t]{3}{*}{2} & 10000 & 9 & 10 & 60.73 & 0.8772 & 8 \\
\hline & & & 10 & 60.61 & 0.8770 & 1 \\
\hline & & & 11 & 52.78 & 0.8736 & 1 \\
\hline \multirow[t]{4}{*}{3} & 10000 & 3 & 10 & 60.73 & 0.8772 & 5 \\
\hline & & & 10 & 60.61 & 0.8770 & 3 \\
\hline & & & 10 & 59.08 & 0.8742 & 1 \\
\hline & & & 12 & 50.39 & 0.8793 & 1 \\
\hline \multirow[t]{3}{*}{4} & 10000 & 1.5 & 10 & 60.73 & 0.8772 & 6 \\
\hline & & & 10 & 60.61 & 0.8770 & 3 \\
\hline & & & 13 & 46.26 & 0.8800 & 1 \\
\hline \multirow[t]{2}{*}{5} & 10000 & 0.8 & 10 & 60.73 & 0.8772 & 6 \\
\hline & & & 10 & 60.61 & 0.8770 & 4 \\
\hline \multirow[t]{3}{*}{6} & 10000 & 0.4 & 10 & 60.73 & 0.8772 & 7 \\
\hline & & & 10 & 60.61 & 0.8770 & 2 \\
\hline & & & 12 & 50.39 & 0.8793 & 1 \\
\hline 7 & 10000 & $0.2^{\mathrm{a}}$ & 10 & 60.73 & 0.8772 & 10 \\
\hline 8 & 10000 & 0.1 & 10 & 60.73 & 0.8772 & 10 \\
\hline 9 & 10000 & 0.075 & 10 & 60.73 & 0.8772 & 10 \\
\hline
\end{tabular}




\begin{tabular}{|c|c|c|c|c|c|c|}
\hline 10 & 20000 & 0.05 & 10 & 60.73 & 0.8772 & 10 \\
\hline \multirow[t]{10}{*}{11} & 10000 & 0.05 & 15 & 38.91 & 0.8795 & 1 \\
\hline & & & 15 & 39.48 & 0.8810 & 1 \\
\hline & & & 14 & 42.72 & 0.8807 & 1 \\
\hline & & & 14 & 41.42 & 0.8774 & 1 \\
\hline & & & 13 & 46.78 & 0.8811 & 1 \\
\hline & & & 13 & 46.59 & 0.8808 & 1 \\
\hline & & & 13 & 46.11 & 0.8797 & 1 \\
\hline & & & 13 & 46.29 & 0.8801 & 1 \\
\hline & & & 12 & 50.39 & 0.8793 & 1 \\
\hline & & & 12 & 50.98 & 0.8805 & 1 \\
\hline
\end{tabular}

a The default

${ }^{\mathrm{b}}$ Number of apparently identical results among the 10 .

Table S1. Descriptors used in this study.

\begin{tabular}{lllllllll}
\hline Compd. & $\Pi$ & LdiG & RV & R $\pi$ & R1V & R1 $\pi$ & R2V & R2 $\pi$ \\
\hline 1 & 406.701 & 0.294 & 0 & 0 & 0 & 0 & 0 & 0 \\
2 & 521.248 & 0.285 & 184.79 & 1.62 & 0 & 0 & 0 & 0 \\
3 & 457.652 & 0.361 & 35.61 & -0.79 & 0 & 0 & 0 & 0 \\
4 & 560.798 & 0.382 & 138.48 & -1.15 & 43.66 & 0.51 & 0 & 0 \\
5 & 467.03 & 0.294 & 43.66 & 0.51 & 43.66 & 0.51 & 0 & 0 \\
6 & 498.139 & 0.343 & 60.99 & -3.91 & 43.66 & 0.51 & 0 & 0
\end{tabular}




\begin{tabular}{|c|c|c|c|c|c|c|c|}
\hline 7 & 464.233 & 0.345 & 0 & 0 & 60.99 & -3.91 & 0 \\
\hline 8 & 503.713 & 0.348 & 52.32 & 0.46 & 60.99 & -3.91 & 0 \\
\hline 9 & 580.954 & 0.322 & 184.79 & 1.62 & 60.99 & -3.91 & 0 \\
\hline 10 & 521.76 & 0.397 & 35.64 & -0.79 & 60.99 & -3.91 & 0 \\
\hline 11 & 497.502 & 0.345 & 43.66 & 0.51 & 60.99 & -3.91 & 0 \\
\hline 12 & 507.677 & 0.347 & 62.81 & 0.79 & 60.99 & -3.91 & 0 \\
\hline 13 & 505.199 & 0.345 & 100.51 & 0.86 & 35.64 & -0.79 & 0 \\
\hline 14 & 452.997 & 0.381 & 9.93 & 0.14 & 35.64 & -0.79 & 0 \\
\hline 15 & 564.528 & 0.349 & 132.79 & 0.26 & 35.64 & -0.79 & 0 \\
\hline 16 & 477.548 & 0.307 & 52.32 & 0.46 & 52.32 & 0.46 & 0 \\
\hline 17 & 503.458 & 0.298 & 100.51 & 0.86 & 52.32 & 0.46 & 0 \\
\hline 18 & 503.068 & 0.321 & 76.54 & -0.26 & 52.32 & 0.46 & 0 \\
\hline 19 & 451.209 & 0.329 & 9.93 & 0.14 & 52.32 & 0.46 & 0 \\
\hline 20 & 567.608 & 0.376 & 138.48 & -1.15 & 52.32 & 0.46 & 0 \\
\hline 21 & 528.164 & 0.331 & 87.68 & -0.43 & 52.32 & 0.46 & 0 \\
\hline 22 & 562.68 & 0.306 & 132.76 & 0.26 & 52.32 & 0.46 & 0 \\
\hline 23 & 434.137 & 0.339 & 52.32 & 0.46 & 0 & 0 & 0 \\
\hline 24 & 459.935 & 0.326 & 100.51 & 0.86 & 0 & 0 & 0 \\
\hline 25 & 460.232 & 0.351 & 76.54 & -0.26 & 0 & 0 & 0 \\
\hline 26 & 490.966 & 0.344 & 134.87 & 0.09 & 0 & 0 & 0 \\
\hline 27 & 448.918 & 0.397 & 35.64 & -0.76 & 0 & 0 & 0 \\
\hline 28 & 457.514 & 0.377 & 60.99 & -3.91 & 0 & 0 & 0 \\
\hline 29 & 484.517 & 0.362 & 62.81 & 0.79 & 35.64 & -0.79 & 0 \\
\hline 30 & 449.76 & 0.316 & 76.54 & -0.26 & 0 & 0 & 0 \\
\hline 31 & 451.371 & 0.342 & 60.99 & -3.91 & 0 & 0 & 0 \\
\hline
\end{tabular}




\begin{tabular}{|c|c|c|c|c|c|c|c|c|}
\hline 32 & 425.042 & 0.302 & 0 & 0 & 43.66 & 0.51 & 0 & 0 \\
\hline 33 & 478.112 & 0.319 & 76.54 & -0.26 & 43.66 & 0.51 & 0 & 0 \\
\hline 34 & 460.258 & 0.305 & 62.81 & 0.79 & 43.66 & 0.51 & 0 & 0 \\
\hline 35 & 479.9 & 0.344 & 60.99 & -3.91 & 43.66 & 0.51 & 0 & 0 \\
\hline 36 & 456.824 & 0.345 & 0 & 0 & 60.99 & -3.91 & 0 & 0 \\
\hline 37 & 510.47 & 0.352 & 76.54 & -0.26 & 60.99 & -3.91 & 0 & 0 \\
\hline 38 & 492.059 & 0.347 & 62.81 & 0.79 & 60.99 & -3.91 & 0 & 0 \\
\hline 39 & 482.81 & 0.346 & 43.66 & 0.51 & 60.99 & -3.91 & 0 & 0 \\
\hline 40 & 472.79 & 0.35 & 0 & 0 & 0 & 0 & 60.99 & -3.91 \\
\hline 41 & 518.898 & 0.34 & 43.66 & 0.51 & 43.66 & 0.51 & 60.99 & -3.91 \\
\hline 42 & 509.736 & 0.349 & 0 & 0 & 60.99 & -3.91 & 0 & 0 \\
\hline 43 & 486.488 & 0.313 & 0 & 0 & 52.32 & 0.46 & 0 & 0 \\
\hline 44 & 404.971 & 0.343 & 0 & 0 & 0 & 0 & 0 & 0 \\
\hline 45 & 429.96 & 0.342 & 43.66 & 0.51 & 0 & 0 & 0 & 0 \\
\hline 46 & 500.42 & 0.334 & 43.66 & 0.51 & 52.32 & 0.46 & 0 & 0 \\
\hline 47 & 522.176 & 0.364 & 0 & 0 & 60.99 & -3.91 & 0 & 0 \\
\hline 48 & 491.55 & 0.326 & 0 & 0 & 52.32 & 0.46 & 0 & 0 \\
\hline 49 & 493.68 & 0.338 & 0 & 0 & 130.12 & -0.5 & 0 & 0 \\
\hline 50 & 545.261 & 0.346 & 43.66 & 0.51 & 130.12 & -0.5 & 0 & 0 \\
\hline 51 & 547.643 & 0.353 & 43.66 & 0.51 & 130.12 & -0.5 & 0 & 0 \\
\hline 52 & 573.371 & 0.352 & 0 & 0 & 130.12 & -0.5 & 0 & 0 \\
\hline 53 & 485.325 & 0.334 & 0 & 0 & 60.99 & -3.91 & 0 & 0 \\
\hline 54 & 420.066 & 0.325 & 0 & 0 & 0 & 0 & 0 & 0 \\
\hline 55 & 475.64 & 0.366 & 0 & 0 & 60.99 & -3.91 & 0 & 0 \\
\hline 56 & 467.473 & 0.329 & 43.66 & 0.51 & 0 & 0 & 0 & 0 \\
\hline
\end{tabular}




\begin{tabular}{|c|c|c|c|c|c|c|c|c|}
\hline 57 & 492.403 & 0.324 & 0 & 0 & 43.66 & 0.51 & 0 & 0 \\
\hline 58 & 440.354 & 0.304 & 0 & 0 & 0 & 0 & 0 & 0 \\
\hline 59 & 448.450 & 0.315 & 0 & 0 & 0 & 0 & 52.32 & 0.46 \\
\hline 60 & 464.890 & 0.310 & 43.66 & 0.51 & 43.66 & 0.51 & 0 & 0 \\
\hline 61 & 490.545 & 0.317 & 43.66 & 0.51 & 52.32 & 0.46 & 0 & 0 \\
\hline 62 & 473.620 & 0.317 & 43.66 & 0.51 & 0 & 0 & 52.32 & 0.46 \\
\hline 63 & 440.070 & 0.311 & 0 & 0 & 43.66 & 0.51 & 0 & 0 \\
\hline 64 & 508.006 & 0.308 & 0 & 0 & 0 & 0 & 52.32 & 0.46 \\
\hline 65 & 414.786 & 0.309 & 0 & 0 & 0 & 0 & 0 & 0 \\
\hline 66 & 468.790 & 0.349 & 0 & 0 & 60.99 & -3.91 & 0 & 0 \\
\hline 67 & 440.070 & 0.311 & 0 & 0 & 43.66 & 0.51 & 0 & 0 \\
\hline 68 & 493.600 & 0.349 & 43.66 & 0.51 & 60.99 & -3.91 & 0 & 0 \\
\hline 69 & 472.521 & 0.302 & 0 & 0 & 0 & 0 & 0 & 0 \\
\hline 70 & 536.975 & 0.341 & 0 & 0 & 43.66 & 0.51 & 60.99 & -3.91 \\
\hline 71 & 542.298 & 0.344 & 0 & 0 & 130.12 & -0.5 & 0 & 0 \\
\hline 72 & 471.096 & 0.255 & 0 & 0 & 0 & 0 & 0 & 0 \\
\hline 73 & 499.148 & 0.256 & 43.66 & 0.51 & 0 & 0 & 0 & 0 \\
\hline 74 & 497.333 & 0.245 & 0 & 0 & 0 & 0 & 0 & 0 \\
\hline 75 & 466.178 & 0.330 & 0 & 0 & 43.66 & 0.51 & 0 & 0 \\
\hline 76 & 529.603 & 0.36 & 0 & 0 & 130.12 & -0.5 & 0 & 0 \\
\hline 77 & 494.23 & 0.329 & 43.66 & 0.51 & 43.66 & 0.51 & 0 & 0 \\
\hline 78 & 439.588 & 0.34 & 0 & 0 & 0 & 0 & 0 & 0 \\
\hline 79 & 466.29 & 0.342 & 0 & 0 & 52.22 & 0.46 & 0 & 0 \\
\hline 80 & 466.79 & 0.308 & 0 & 0 & 43.66 & 0.51 & 0 & 0 \\
\hline 81 & 495.102 & 0.33 & 87.68 & -0.43 & 0 & 0 & 0 & 0 \\
\hline
\end{tabular}




\begin{tabular}{|c|c|c|c|c|c|c|c|c|}
\hline 82 & 498.752 & 0.297 & 100.51 & 0.86 & 43.66 & 0.51 & 0 & 0 \\
\hline 83 & 525.65 & 0.333 & 87.68 & -0.43 & 43.66 & 0.51 & 0 & 0 \\
\hline 84 & 397.106 & 0.3 & 0 & 0 & 0 & 0 & 0 & 0 \\
\hline 85 & 422.625 & 0.302 & 43.66 & 0.51 & 0 & 0 & 0 & 0 \\
\hline 86 & 505.14 & 0.373 & 60.99 & -3.91 & 60.99 & -3.91 & 0 & 0 \\
\hline 87 & 431.86 & 0.303 & 62.81 & 0.79 & 0 & 0 & 0 & 0 \\
\hline 88 & 445.99 & 0.315 & 0 & 0 & 52.32 & 0.46 & 0 & 0 \\
\hline 89 & 496.72 & 0.341 & 0 & 0 & 43.66 & 0.51 & 60.99 & -3.91 \\
\hline 90 & 439.68 & 0.309 & 43.66 & 0.51 & 0 & 0 & 0 & 0 \\
\hline 91 & 503.889 & 0.35 & 43.66 & 0.51 & 0 & 0 & 60.99 & -3.91 \\
\hline 92 & 512.653 & 0.349 & 0 & 0 & 0 & 0 & 60.99 & -3.91 \\
\hline 93 & 427.79 & 0.326 & 0 & 0 & 0 & 0 & 0 & 0 \\
\hline 94 & 450.52 & 0.332 & 0 & 0 & 52.32 & 0.46 & 0 & 0 \\
\hline 95 & 466.078 & 0.322 & 0 & 0 & 0 & 0 & 0 & 0 \\
\hline 96 & 472.615 & 0.309 & 0 & 0 & 52.32 & 0.46 & 0 & 0 \\
\hline
\end{tabular}

Table S1 (cont.)

Compd. I(Pyr) I(Imi) I(Thi) (ICH2) (ICH2 $\mathrm{IC}_{2}\left(\mathrm{ICH}_{2} \mathrm{~S}\right)\left(\mathrm{IC}_{2} \mathrm{H}_{4}\right)\left(\mathrm{ICH}_{2} \mathrm{NH}\right) \Delta \mathrm{H}_{\mathrm{S}}$

\begin{tabular}{llllllllll}
\hline 1 & 0 & 0 & 0 & 0 & 0 & 0 & 0 & 0 & -9.848 \\
2 & 0 & 0 & 0 & 0 & 0 & 0 & 0 & 0 & -9.804 \\
3 & 0 & 0 & 0 & 0 & 0 & 0 & 0 & 0 & -15.536 \\
4 & 0 & 0 & 0 & 0 & 0 & 0 & 0 & 0 & -19.403 \\
5 & 0 & 0 & 0 & 0 & 0 & 0 & 0 & 0 & -9.749 \\
6 & 0 & 0 & 0 & 0 & 0 & 0 & 0 & 0 & -18.327 \\
7 & 0 & 0 & 0 & 0 & 0 & 0 & 0 & 0 & -17.944
\end{tabular}




\begin{tabular}{|c|c|c|c|c|c|c|c|c|c|}
\hline 8 & 0 & 0 & 0 & 0 & 0 & 0 & 0 & 0 & -17.978 \\
\hline 9 & 0 & 0 & 0 & 0 & 0 & 0 & 0 & 0 & -17.786 \\
\hline 10 & 0 & 0 & 0 & 0 & 0 & 0 & 0 & 0 & -23.243 \\
\hline 11 & 0 & 0 & 0 & 0 & 0 & 0 & 0 & 0 & -18.137 \\
\hline 12 & 0 & 0 & 0 & 0 & 0 & 0 & 0 & 0 & -18.761 \\
\hline 13 & 0 & 0 & 0 & 0 & 0 & 0 & 0 & 0 & -15.385 \\
\hline 14 & 0 & 0 & 0 & 0 & 0 & 0 & 0 & 0 & -15.448 \\
\hline 15 & 0 & 0 & 0 & 0 & 0 & 0 & 0 & 0 & -18.701 \\
\hline 16 & 0 & 0 & 0 & 0 & 0 & 0 & 0 & 0 & -9.993 \\
\hline 17 & 0 & 0 & 0 & 0 & 0 & 0 & 0 & 0 & -9.883 \\
\hline 18 & 0 & 0 & 0 & 0 & 0 & 0 & 0 & 0 & -12.841 \\
\hline 19 & 0 & 0 & 0 & 0 & 0 & 0 & 0 & 0 & -9.983 \\
\hline 20 & 0 & 0 & 0 & 0 & 0 & 0 & 0 & 0 & -20.451 \\
\hline 21 & 0 & 0 & 0 & 0 & 0 & 0 & 0 & 0 & -14.198 \\
\hline 22 & 0 & 0 & 0 & 0 & 0 & 0 & 0 & 0 & -13.151 \\
\hline 23 & 1 & 0 & 0 & 0 & 0 & 0 & 0 & 0 & -14.627 \\
\hline 24 & 1 & 0 & 0 & 0 & 0 & 0 & 0 & 0 & -14.514 \\
\hline 25 & 1 & 0 & 0 & 0 & 0 & 0 & 0 & 0 & -17.444 \\
\hline 26 & 1 & 0 & 0 & 0 & 0 & 0 & 0 & 0 & -17.368 \\
\hline 27 & 1 & 0 & 0 & 0 & 0 & 0 & 0 & 0 & -20.186 \\
\hline 28 & 1 & 0 & 0 & 0 & 0 & 0 & 0 & 0 & -23.076 \\
\hline 29 & 0 & 0 & 0 & 0 & 0 & 0 & 0 & 0 & -15.828 \\
\hline 30 & 0 & 0 & 0 & 1 & 0 & 0 & 0 & 0 & -14.36 \\
\hline 31 & 0 & 0 & 0 & 1 & 0 & 0 & 0 & 0 & -20.271 \\
\hline 32 & 0 & 0 & 0 & 1 & 0 & 0 & 0 & 0 & -11.057 \\
\hline
\end{tabular}


33

$34 \quad 0 \quad 0 \quad 0 \quad 1 \quad 0$

$\begin{array}{llllll}34 & 0 & 0 & 0 & 1 & 0 \\ 35 & 0 & 0 & 0 & 1 & 0\end{array}$

35

36 37 38

39

40

4

41

4

43

44

44

$\begin{array}{llllll}45 & 1 & 0 & 0 & 0 & 1\end{array}$

$46 \quad 0 \quad 1 \quad 0 \quad 0 \quad 0$

$\begin{array}{llllll}47 & 0 & 1 & 0 & 0 & 1\end{array}$

$48 \quad 0 \quad 1 \quad 00000$

$49 \quad 0 \quad 0 \quad 0 \quad 0 \quad 0$

$\begin{array}{llllll}50 & 0 & 0 & 0 & 0 & 1\end{array}$

$\begin{array}{lllllllll}51 & 0 & 1 & 0 & 0 & 1 & 0 & 0 & 0\end{array}$

$\begin{array}{lllllllll}52 & 0 & 1 & 0 & 0 & 0 & 1 & 0 & 0\end{array}$

$\begin{array}{lllllllll}53 & 0 & 0 & 0 & 0 & 0 & 0 & 1 & 0\end{array}$

$\begin{array}{llllllll}54 & 1 & 0 & 0 & 0 & 0 & 0 & 1\end{array}$

$\begin{array}{lllllllll}55 & 0 & 1 & 0 & 0 & 1 & 0 & 0 & 0\end{array}$

$\begin{array}{lllllllll}56 & 0 & 1 & 0 & 0 & 1 & 0 & 0 & 0\end{array}$

$\begin{array}{lllllllll}57 & 0 & 1 & 0 & 0 & 0 & 1 & 0 & 0\end{array}$

$-14.106$

$-12.008$

$-20.223$

$-19.249$

$-22.279$

$-20.381$

$-19.705$

$-21.727$

$-21.42$

$-21.898$

$-13.586$

$-18.062$

$-18.244$

$-16.884$

$-24.324$

$-16.072$

$-24.076$

$-20.641$

$-26.808$

$-23.133$

$-19.897$

$-16.423$

$-24.965$

$-16.789$

$-16.111$ 


\begin{tabular}{|c|c|c|c|c|c|c|c|c|c|}
\hline 58 & 0 & 1 & 0 & 0 & 0 & 0 & 1 & 0 & -16.217 \\
\hline 59 & 0 & 0 & 0 & 0 & 1 & 0 & 0 & 0 & -13.575 \\
\hline 60 & 0 & 0 & 0 & 0 & 1 & 0 & 0 & 0 & -13.588 \\
\hline 61 & 0 & 0 & 0 & 0 & 1 & 0 & 0 & 0 & -14.605 \\
\hline 62 & 0 & 0 & 0 & 0 & 1 & 0 & 0 & 0 & -13.588 \\
\hline 63 & 0 & 0 & 0 & 0 & 1 & 0 & 0 & 0 & -13.478 \\
\hline 64 & 0 & 0 & 0 & 0 & 0 & 1 & 0 & 0 & -13.898 \\
\hline 65 & 0 & 0 & 0 & 0 & 1 & 0 & 0 & 0 & -13.572 \\
\hline 66 & 0 & 0 & 0 & 0 & 1 & 0 & 0 & 0 & -21.797 \\
\hline 67 & 0 & 0 & 0 & 0 & 1 & 0 & 0 & 0 & -13.479 \\
\hline 68 & 0 & 0 & 0 & 0 & 1 & 0 & 0 & 0 & -22.149 \\
\hline 69 & 0 & 0 & 0 & 0 & 0 & 1 & 0 & 0 & -13.869 \\
\hline 70 & 0 & 0 & 0 & 0 & 0 & 1 & 0 & 0 & -21.277 \\
\hline 71 & 0 & 0 & 0 & 0 & 0 & 1 & 0 & 0 & -19.747 \\
\hline 72 & 0 & 0 & 1 & 0 & 1 & 0 & 0 & 0 & -13.876 \\
\hline 73 & 0 & 0 & 1 & 0 & 1 & 0 & 0 & 0 & -14.13 \\
\hline 74 & 0 & 0 & 1 & 0 & 0 & 1 & 0 & 0 & -13.202 \\
\hline 75 & 0 & 1 & 0 & 0 & 1 & 0 & 0 & 0 & -16.457 \\
\hline 76 & 0 & 1 & 0 & 0 & 1 & 0 & 0 & 0 & -22.73 \\
\hline 77 & 0 & 1 & 0 & 0 & 1 & 0 & 0 & 0 & -16.975 \\
\hline 78 & 0 & 1 & 0 & 0 & 0 & 0 & 0 & 1 & -17.349 \\
\hline 79 & 0 & 1 & 0 & 0 & 0 & 0 & 0 & 1 & -18.79 \\
\hline 80 & 0 & 1 & 0 & 0 & 0 & 0 & 1 & 0 & -16.397 \\
\hline 81 & 0 & 0 & 0 & 0 & 0 & 0 & 0 & 0 & -14.129 \\
\hline 82 & 0 & 0 & 0 & 0 & 0 & 0 & 0 & 0 & -9.71 \\
\hline
\end{tabular}




\begin{tabular}{llllllllll}
83 & 0 & 0 & 0 & 0 & 0 & 0 & 0 & 0 & -13.92 \\
84 & 0 & 0 & 0 & 1 & 0 & 0 & 0 & 0 & -11.311 \\
85 & 0 & 0 & 0 & 1 & 0 & 0 & 0 & 0 & -11.548 \\
86 & 0 & 0 & 0 & 1 & 0 & 0 & 0 & 0 & -29.181 \\
87 & 0 & 0 & 0 & 1 & 0 & 0 & 0 & 0 & -12.177 \\
88 & 0 & 0 & 0 & 0 & 1 & 0 & 0 & 0 & -13.568 \\
89 & 0 & 0 & 0 & 0 & 1 & 0 & 0 & 0 & -21.341 \\
90 & 0 & 0 & 0 & 0 & 1 & 0 & 0 & 0 & -13.588 \\
91 & 0 & 0 & 0 & 0 & 1 & 0 & 0 & 0 & -21.774 \\
92 & 0 & 0 & 0 & 0 & 0 & 1 & 0 & 0 & -21.593 \\
93 & 0 & 1 & 0 & 0 & 1 & 0 & 0 & 0 & -16.081 \\
94 & 0 & 1 & 0 & 0 & 1 & 0 & 0 & 0 & -16.763 \\
95 & 0 & 1 & 0 & 0 & 0 & 1 & 0 & 0 & -16.036 \\
96 & 0 & 1 & 0 & 0 & 0 & 0 & 1 & 0 & -16.313 \\
\hline
\end{tabular}




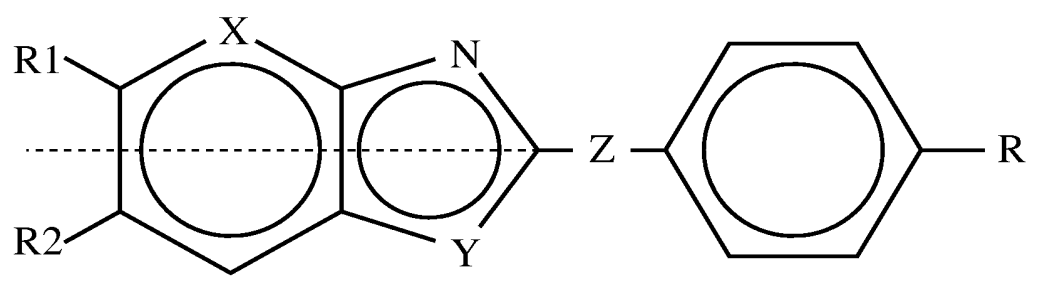

Figure 1

Structure and symmetry of the compounds considered 
Figure 2. Correlation of observed p MIC versus estimated.

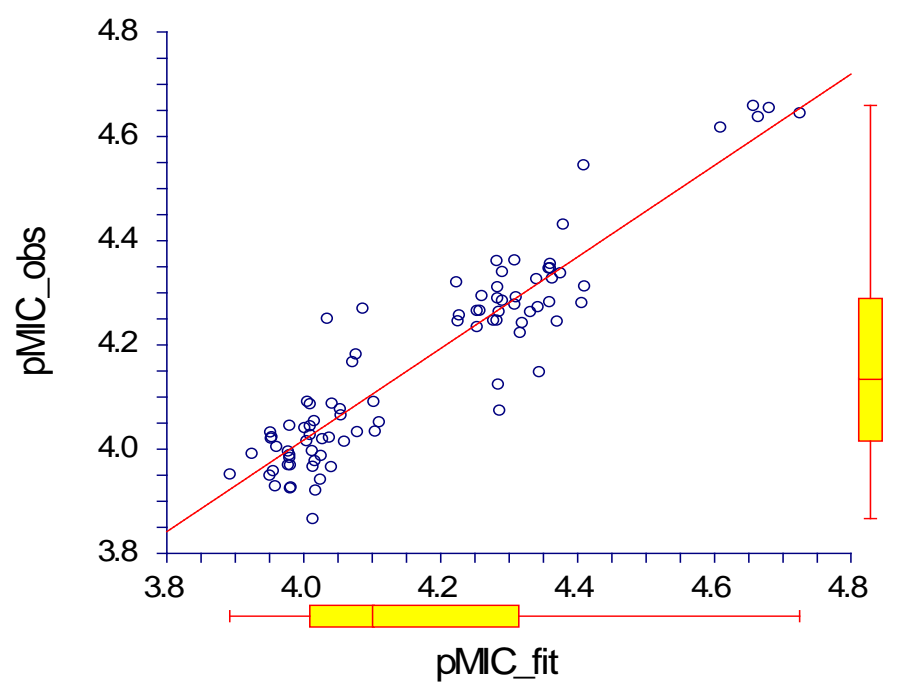

